\title{
Avant-propos : Le cinquantième numéro
}

Foreword: The fiftieth Issue

\section{Suzanne Baudemont}

\section{CpenEdition}

\section{Journals}

Édition électronique

URL : http://journals.openedition.org/rfcb/3228

DOI : $10.4000 /$ rfcb.3228

ISSN : 2429-4373

Éditeur

CRECIB - Centre de recherche et d'études en civilisation britannique

\section{Édition imprimée}

Date de publication : 1 septembre 2004

ISBN : 2-911580-19-2

ISSN : 0248-9015

\section{Référence électronique}

Suzanne Baudemont, «Avant-propos : Le cinquantième numéro », Revue Française de Civilisation

Britannique [En ligne], XIII-1 | 2004, mis en ligne le 01 septembre 2004, consulté le 25 septembre 2020. URL : http://journals.openedition.org/rfcb/3228 ; DOI : https://doi.org/10.4000/rfcb.3228

Ce document a été généré automatiquement le 25 septembre 2020.

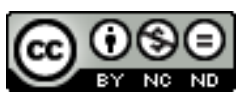

Revue française de civilisation britannique est mis à disposition selon les termes de la licence Creative Commons Attribution - Pas d'Utilisation Commerciale - Pas de Modification 4.0 International. 


\title{
Avant-propos : Le cinquantième numéro
}

Foreword: The fiftieth Issue

\author{
Suzanne Baudemont
}

1 Qui, parmi les pionniers qui participèrent au lancement de la Revue française de civilisation britannique, aurait misé un penny sur sa survie jusqu'à ce terme? Il est vrai que dans l'enthousiasme - faut-il parler d'inconscience ? - qui présida à cette initiative, nous ne nous posions pas la question de sa longévité. La Revue avait été créée, il fallait la faire vivre, au jour le jour, même si l'expérience et surtout le nerf de la guerre nous faisaient cruellement défaut.

2 "Dorénavant notre revue paraîtra deux fois par an", annonce avec confiance Robert PALACIN (Toulouse Le Mirail), alors Président du CRECIB, dans son avant-propos au n ${ }^{\circ} 1$, vol. I. Nous savions en effet que la matière ne manquait pas et la difficulté, lors des réunions du Comité, était d'opérer un classement parmi les nombreuses propositions de thèmes qui nous parvenaient, toutes accompagnées d'un solide ensemble d'articles.

3 Mais ensuite commençait pour le « responsable » désigné la chasse aux subventions et crédits : la liste des Universités et Centres de Recherches grâce au concours desquels chaque numéro put voir le jour donne un aperçu du nombre de démarches entreprises.

4 J'ai déjà exprimé, dans les Mélanges en son honneur, notre gratitude envers Monica CHARLOT, qui fut à l'origine de cette audacieuse création. Mais je tiens également à témoigner ici de l'aide que j'ai reçue de la part de ceux qui ont assuré avec exigence et dévouement la tâche ingrate de trésorier: Jean-Luc JULIENNE (Brest) puis Jacques LERUEZ (CNRS), ainsi que de la part de tous les membres du CRECIB. Tous les Directeurs de la publication qui se sont succédé en conviendront: notre Revue fut et reste vraiment une œuvre collective, dont nous pouvons être fiers et à qui je souhaite longue vie. 


\section{AUTEUR}

\section{SUZANNE BAUDEMONT}

Directrice de la publication de la Revue française de civilisation britannique, 1980-85

Présidente du CRECIB, 1981-85 